УДК 7.067 (477)

Беда Ольга Михайлівна, аспірантка кафедри академічного й естрадного вокалу та звукорежисури

Національної академії керівних

кадрів культури і мистецтв olabeda888@gmail.com

ORCID 0000-0001-7048-8302

\title{
АНДЕГРАУНД В УКРАЇНСЬКІЙ МУЗИЦІ НЕАКАДЕМІЧНОЇ ТРАДИЦЇ̈
}

Мета роботи. У дослідженні розглянуто андеграундну музику неакадемічної традиції в контексті розвитку українського музичного мистецтва радянської й пострадянської доби. Методологія дослідження передбачає використання історико-культурного методу, який дозволив виокремити віхи української андеграундної неакадемічної музики. Наукова новизна роботи полягає в тому, що вперше в українській науці було розглянуто андеграунд в музиці неакадемічної традиції в ії історичній динаміці, визначено та охарактеризовано два типи андеграундної музики - нонконформістський та нішевий. Висновки. Андеграунд як підпільне мистецтво в різних типах суспільства має різні соціокультурні функції. У тоталітарних суспільствах андеграундним є й елітарне, й масове мистецтво, яке має яскраво виражений нонконформістський характер, а його зміст спрямований на подолання обмеження прав і свобод людини, а також творчого волевиявлення митця. У відкритих суспільствах андеграунд стає своєрідним самовираженням творчої еліти й спрямований на вузьку аудиторію, сьогодні він має яскраво виражений нішевий характер. Творчість українських ейсид-джазових колективів «Jungleman», «4.A.Й.К.А», «Lюk» $\epsilon$ репрезентантом андеграунду пострадянської доби, якому властивий елітарний характер музики та відсутність промоції шоу-бізнесового типу.

Ключові слова: андеграунд, нонконформізм, джаз, рок, ейсид-джаз, творчість гуртів «Јungleman», «4.А.Й.К.А» та «Lюk».

Беда Ольга Михайловна, аспирантка кафедры академического и эстрадного вокала и звукорежиссуры Национальной академии руководящих кадров культуры и искусств

Андеграунд в украинской музыке неакадемической традиции

Цель работы. В исследовании рассмотрена андеграундная музыка неакадемической традиции в контексте развития украинского музыкального искусства советской и постсоветской эпохи. Методология исследования предполагает использование историко-культурного метода, который позволил выделить вехи украинского андеграундной неакадемической музыки. Научная новизна работы заключается в том, что впервые в украинской науке был рассмотрен андеграунд в музыке неакадемической традиции в ее исторической динамике, определены и охарактеризованы два типа андеграундной музыки - нонконформистский и нишевый. Выводы. Андеграунд как подпольное искусство в различных типах общества имеет различные социокультурные функции. В тоталитарных андеграундным является и элитарное, и массовое искусство, которое имеет ярко выраженный нонконформистский характер, а его содержание направлено на преодоление ограничения прав и свобод человека, а также творческого волеизъявления художника. В открытых обществах андеграунд становится своеобразным самовыражением творческой элиты и направлен на узкую аудиторию, сегодня он имеет ярко выраженный нишевый характер. Творчество украинских эйсид-джазовых коллективов «Jungleman», «4.A.Й.К.A», «Lюk» является репрезентантом андеграунда постсоветской эпохи, для которого характерны элитарный характер музыки и отсутствие промоции, принятой в шоу-бизнесе.

Ключевые слова: андеграунд, нонконформизм, джаз, рок, эйсид-джаз, творчество групп «Jungleman», «4.А.Й.К.А» и «Lюk».

Beda Olga, Postgraduate Student of the Department of Academic and Variety Vocal and Sound Directing of the National Academy of Managerial Staff of Culture and Arts

Underground in Ukrainian music of non-academic tradition

The purpose of the article. The study considers underground music of a non-academic tradition in the context of the development of Ukrainian musical art in the Soviet and post-Soviet times. The methodology of the research involves the use of the historical-cultural method, which allowed to highlight the milestones of the Ukrainian underground non-academic music. The scientific novelty of the research consists in the fact that for the first time in the Ukrainian science the underground in the music of the non-academic tradition in its historical dynamics was considered, two types of underground music were defined and characterized - nonconformist and niche. Conclusions. Underground as "underground" art in different types of society has different socio-cultural functions. The totalitarian underground is both elitist and mass art, which has a pronounced nonconformist character, and its content is aimed at overcoming the restriction of human rights and freedoms, as well as the creative will of the artist. In open societies, the underground becomes peculiar self-expression of the creative elite and is aimed at a narrow audience; today, it has a pronounced niche character. The creativity of the Ukrainian jazz groups "Jungleman," "4.A.Y.K.A.", "Luk" is a representative of the underground of the post-Soviet era, which is characterized by the elitist nature of music and the lack of promotion adopted in the show business. and "Luк."

Key words: underground, nonconformism, jazz, rock, acid jazz, the creativity of groups "Jungleman," "4.A.Y.K.A,"

СБеда О. М., 2019 
Актуальність теми дослідження. Постмодерне мистецтво відзначається розмаїттям напрямів, стилів, жанрів, форм. Сьогодні, плануючи той чи інший популярний музичний проект, часто неможливо передбачити його перспективу, оскільки грані між комерційним та некомерційним мистецтвом дуже прозорі. Так у свій час музика чорношкірих не приймалася білим населенням Америки, однак 3 часом блюз i джаз, а пізніше реп стали успішними напрямами світової популярної музики. Саме тому говорити про андеграунд у мистецтві, зокрема музичному, - як академічному, так і неакадемічному - іноді важко. Проте напрями неакадемічної музики є різноманітними, і деякі з них у певний період розвитку можна вважати андеграундним. Їхнє значення для культури й мистецтва $є$ не менш важливим, ніж офіційно визнаного мистецтва, а тому вказані напрями потребують уваги дослідників.

Аналіз останніх досліджень та публікацій. Сьогодні в українській науці відсутні роботи, в яких системно висвітлено андеграундне мистецтво. Причина цього - певна маргінальність андеграунду в культурному просторі. Як зазначено в культурологічному словнику, андеграунд - це «“підпільні” течії в сучасній культурі, для яких характерно розрив з панівною ідеологією, відмова від загальноприйнятих цінностей, норм, традицій, нерідко порушення художніх форм, бунтарство, епатаж публіки» [1, 22-23]. Отже, андеграундне мистецтво не $\epsilon$ його провідною течією, воно часто стає художньою формою вираження світогляду різних субкультур, іноді - репрезентантом представників контркультури. Однак що саме можна вважати андеграундом, залежить від точки зору як дослідника, так і панівної ідеології. У радянські часи рокмузику розглядали як частину молодіжної субкультури, іноді контркультури, оскільки рок-музиканти переслідувалися радянською владою й низка гуртів вела напівпідпільний спосіб існування. Однак сьогодні ніхто $з$ дослідників не розглядає рок-музику як субкультуру або контркультуру, оскільки значення року для розвитку й світового, й національного мистецтва вже не підлягає сумніву.

Близьким до андеграунду за значенням $\epsilon$ поняття «нонконформізм», яке, як і контркультура, також $\epsilon$ протестним напрямом. Якщо в музичному мистецтві поняття «андеграунд» $\mathrm{i}$ «нонконформізм» ще детально не розроблені, то в образотворчому дослідженню нонконформізму в історичній динаміці присвячена дисертація Л. Смирної. Дослідниця, аналізуючи творчість українських художників у контексті нонконформізму, часто вживає й дефініцію «андеграунд» як його синонім. Втім Л. Смирна розділяє ці поняття, бо їхій зміст збігається лише частково. Так вона зазначає, що андеграунд у СРСР - це радикальний альтернативний соціум, метою якого став спротив тоталітарно-ідеологічним настановам, він був своєрідною формою ставлення людини до буття, а тому виходив за рамки мистецтва $[6,59]$. На думку Л. Смирної, андеграунд як поняття $є$ вужчим, ніж нонконформізм $[6,73]$, оскільки останній ототожнюється 3 протистоянням радянському режиму. Нонконформістське мистецтво може змінюватися андеграундним, як це сталося у 1970-ті рр., коли воно перейшло «... з етико-політичного простору протистояння режиму в ігровий формат молодіжно-контроверсійного андеграунду» $[6,25]$. Таким чином, нонконформізм у часи СРСР створив «... стійку форму мистецької опозиції із власним художнім тезаурусом, іконографією тем $\mathrm{i}$ сюжетів $<\ldots>$, естетичними уподобаннями $<\ldots>$, персоніфікованою мистецькою мовою, чітким баченням об'єкта заперечення та розумінням того, що їхній протест вже не можна приховати». Стратегії функціонування класичного нонконформізму створили простір його міської інфраструктури $[6,61]$.

Л. Смирна пропонує власну хронологію нонконформізму в українському мистецтві, що має такі етапи: «“протононконформізм” (національний рух в мистецтві 1920-1930-х), “класичний нонконформізм” (протестні рухи в культурі 1960-1980-х), “зрілий нонконформізм” (пізньорадянський період 1985-1991), “посткласичний нонконформізм” або "постнонконформізм” (сучасні реалії симулякрових протестівфлешмобів, політизація мистецтва, антитеза політизації та утилізації мистецтва у вигляді звернення до народного мистецтва, архаїки 1990-2000-х)» [6, 3]. Однак у роботі при описі творчості митців часто вживається термін «андеграунд», ці поняття часто синонімизуються, хоча різниця їхнього змісту для автора $\epsilon$ цілком очевидною. Таким чином, поняття андеграунду в мистецтві радянської й частково пострадянської доби тісно змикається з нонконформізмом, однак не є тотожним йому. I якщо ці питання розглядалися в контексті розвитку образотворчого мистецтва, то в музиці андеграунд як окреме явище не ставав предметом спеціального дослідження. На сьогоднішній день $є$ значна за обсягом література, де розглянуто музику 1960-1970-х рр. (переважно академічну), де творчість митців-шістдесятників вивчалася як опозиційна до провідного стилю радянської доби - соціалістичного реалізму, й значно менш дослідженою в цьому контексті є музика неакадемічної традиції, яка не $є$ менш показовою.

Мета статті полягає в розгляді андеграундної музики неакадемічної традиції в контексті розвитку українського музичного мистецтва радянської й пострадянської доби.

Виклад основного матеріалу. Популярна музика, особливо певні ії види, стилі та напрями, в радянські часи були фактично андеграундним мистецтвом. Так у 1920-х і особливо 1930-х рр. угисків зазнавали не лише авангардні течії академічної музики, а й джаз. Джаз як напрям популярної музики не підтримувався радянською владою, хоча саме у цей час з'являються відомі джазові оркестри - «Перший ексцентричний оркестр - джаз-банд Валентина Парнаха» (1922), харківський джазовий ансамбль 3 шести виконавців під орудою Ю. Мейтуса (1924), джазовий оркестр Л. Теплицького (1927), «АМА-джаз» О. Цфасмана (1927) та ін. При цьому не варто забувати, що джазова музика, виконувана цими колективами, була вельми далекою від 
класичного американського джазу, однак цілком зрозумілою для широкої публіки, що проживала в СРСР. Справжній негритянський джаз, напевно, сприймався б слухачами як андеграунд, як музика для небагатьох, але не 3 причин політичних чи ідеологічних, а музично-естетичних. Однак посилення ідеологічного компоненту в радянській естраді повоєнної доби призвели до того, що джазова музика стала андеграундом, як це було наприкінці 1940-х рр., коли у постанові ЦК КПРС 1948 р. було рекомендовано «... визнати джазову музику й оджазовану естраду як шкідливу творчість, а вживання слова “джаз” заборонити у засобах масової інформації. Під заборону потрапило буквально все, що було пов’язане або нагадувало про джаз» [5, 75]. Творчість видатних естрадних діячів, що використовували джазові ритми (Л. Утьосов, О. Цфасман та ін.), фактично ставала андеграундним мистецтвом. I лише після смерті Й. Сталіна джаз й естрада знову повернулися до більш-менш вільного розвитку. Таким чином, у СРСР джаз як музичний напрям у певні періоди ставав андеграундним мистецтвом з різних причин - ідеологічної та музично-естетичної.

Аналогічна історія у 1960-х pp. була і з рок-музикою. Цілком прогнозовано вона спочатку не сприймалася радянською владою й відразу ж потрапила під заборону. Ю. Дружкін, говорячи про рокмузику, відзначає, що вона в СРСР спочатку повністю заборонялася, потім частково дозволялася, але контролювалася владою, а пізніше використовувалася нею з ідеологічною метою [2, 14]. У 1970-х - на початку 1980-х рр. рок-музика у СРСР, хоч і контрольовано, але розвивалася. Більш активно розвивалися фольклорні BIA, менше - колективи, що прагнули грати «справжній» рок. Якщо в СРСР усі рок-музиканти зазнавали утисків за поширення «буржуазної» музики, то україномовним гуртам закидали ще й «буржуазний націоналізм». Відомий у 1960-х рр. київський гурт «Березень» спочатку мав назву «МаріяОранта», однак з цією назвою, що відсилала до національних релігійних традицій, колективу не дозволили виступати. Тоді музиканти змінили назву на «Березень», але «... якісь начальники угледіли якийсь кримінал і в цій назві, пов’язавши їі з театром Курбаса - “Березіль”» [3, 56]. Згадаємо й долю україномовного гурту «Еней» на початку 1970-х рр., коли черговий раз посилився наступ не лише на рок-музику, а й творчість українських поетів та письменників [3, 68-69]. Діяльність рок-музикантів значно пожвавився перед Олімпіадою 1980 р., яка проводилася у Москві, однак після сплеску рок-творчості наступила реакція 19831985 рр., коли колективи й окремі музиканти переслідувалися, і лише горбачовська перебудова припинила це ганебне явище [5, 109-110]. Як бачимо, історія з рок-музикою практично повністю повторила історію джазу в СРСР: несприйняття - активний розвиток - заборона та переслідування - вільний розвиток. І саме в період заборони джаз і рок ставали андеграундним мистецтвом, творчість джазових та рок-музикантів тоді мала переважно нонконформістський характер.

Андеграунд як напрям художньої творчості не зник з розпадом СРСР, але змінився його характер. А. Январська, розмірковуючи про український андеграунд кінця 1980-х - 1990-х рр., згадує різні колективи. Одні з них поєднували андеграундний епатаж 3 критикою радянської влади («ванов Даун»), але переважав «чистий» андеграунд («Фоа Хока», «Пірата Бенд», «Цвіркунове число», «Цукор біла смерть», «Минула юнь» та ін.) [7]. У підборі матеріалу щодо висвітлення українського андеграунду кінця 1980-х - 1990-х рр., цілком доречному, є певні диспропорції: авторка до андеграунду, наприклад, віднесла такі популярні гурти як «Раббота Хо», «Колезький асесор», «ВВ», музика яких хоча й була експериментальною, особливо в СРСР або відразу після його розпаду, однак збирала величезні аудиторії на батьківщині та за кордоном.

Окрім переслідування у СРСР джазу, а потім року, українська національно орієнтована музика всіх напрямів також постійно зазнавала тиску. Україномовні виконавці, окрім 1970-х рр., завжди витискувалися на маргінес. Ситуацію змінилася лише наприкінці 1980-х рр. На першому фестивалі української музики «Червона рута», що відбувся у 1989 р. у Чернівцях, 35 рок-гуртів, 78 поп-виконавців та гуртів, 48 бардів вийшли «з тіні невідомості, другосортності» [3, 255], тобто 3 андеграунду. Першу «Червону рута» можна розглядати як андеграунд нонконформістського плану, оскільки були спроби місцевої влади провести рокконцерти фестивалю поза межами міста, іï представники намагалися не допустити до участі у фестивалі 600 учасників 3 1500, відключали струм під час виступів, хотіли змінити фінальний виступ Тараса Петриненка, заборонивши йому на заключному концерті виконувати пісню «Народний рух» [3, 255-256]. Але в результаті діяльності «Червоної рути» українська популярна музика усіх напрямів та жанрів вийшла 3 підпілля і стала розвиватися природним шляхом.

Відповідно до зазначеного вище можна зробити висновок, що ідеологічний тиск породив своєрідний феномен, властивий тоталітарним суспільствам: андеграундом могло стати не лише малозрозуміле для широкої публіки елітарне мистецтво, а й музичний мейнстрім, який у відкритих суспільствах не просто не був заборонений, а приносив неабиякий комерційний зиск. Джаз і рок на момент їх переслідування в СРСР у нетоталітарних країнах були музичним мистецтвом, популярним серед широкого загалу. У СРСР у певні періоди популярна, тобто розважальна за своєю суттю, музика мала нонконформістський характер через іï заборону.

Андеграундність масової музики - явище нетипове й притаманне лише тоталітарним суспільствам. Цю тезу можна заперечити, згадавши, що у свій час музичні жанри чорношкірих американців (спірічуел, госпел, блюз, реп) були для білих свого роду андеграундом, а пізніше стали комерційно успішним мистецтвом. Однак ця аналогія є хибною, бо названі жанри в час їхнього андеграундного функціонування 
не були музикою розважальною: спірічуел і госпел - це духовні піснеспіви, блюз і реп - особистісна лірика, яка має яскраво виражену соціальну спрямованість, а тому дуже далека від розважальності. Тож ці та інші жанри «чорної» музики стали комерційно успішними лише тоді, коли були «почуті», як це вказує у своїй роботі В. Конен [4], білими американцями. До цього часу афроамериканська музика не заборонялася, але була на маргінесі американської культури - сьогодні б ці співи назвалися субкультурою афроамериканців. Однак новизна музичної мови, яка різко відрізнялася від того, що продукувала масова культура білих, 3 часом зробила блюз, джаз і реп популярною музикою для усіх. Саме тому ми можемо говорити про унікальність СРСР (а також й інших тоталітарних суспільств), де масова музика у певні періоди ставала андеграундом і набувала нонконформістських рис.

Картина радикально змінюється в пострадянську добу, коли не стало тоталітарного контролю над суспільством і не було потреби забороняти нові стилі західної популярної музики. Саме тоді деякі їі жанри, стилі та напрями чи не вперше перестають бути андеграундом і починають вільно розвиватися. Однак через певний час низка жанрів, напрямів та стилів залишається популярною, а частина стає менш цікавою широкій публіці. Такою музикою сьогодні, наприклад, є джаз. Як показує практика, джазові фестивалі збирають велику кількість людей, особливо коли туди приїжджають зірки світового рівня. Водночас джаз не лише в Україні, а і в усьому світі є мистецтвом елітарним і тому певною мірою андеграундним. Однак андеграундність сьогодні в пострадянських країнах набуває іншого значення, вже більш близького до світового. Нині андеграундне мистецтво визначають як нішеве, тобто таке, яке має свою специфічну аудиторію, своїх слухачів/читачів/глядачів. Воно не забороняється, але спеціально не підтримується, а тому розвивається в рамках окремих культурних прошарків - субкультур. Андеграундне мистецтво, безумовно, не тотожне субкультурному (іноді воно позиціонує себе як елітарне), однак споріднене 3 ним через спрямованість на малу (часто специфічну) аудиторію.

Андеграундне мистецтво є ширшим, ніж субкультурне, оскільки у певний момент може стати мейнстрімом (як це сталося з блюзом або репом), тоді як мистецтво субкультур не має потреби виходити за iii межі. Щодо нішевого мистецтва, то воно є дещо відмінним від андеграундного, але в іншій площині функціональній. Музика для дітей, фольклорна музика тощо - це мистецтво нішеве, однак навряд чи його можна вважати андеграундом. Однак сучасний андеграунд, що в добу постмодерну фактично втратив нонконформістські риси, теж стає окремою нішею - нішею елітарного мистецтва.

Розглянемо деякі напрями сучасної української музики, яку позиціонуємо до андеграундну або нішеву. Вже зазначалося, що джаз є мистецтвом елітарним, а тому має навіть меншу аудиторію, ніж класична музика. I якщо традиційний джаз є більш популярним серед любителів джазової музики, то експериментальні його форми $є$ андеграундом у чистому вигляді, а тому мають свою, часто вузьку, аудиторію. Серед «некласичних» джазових напрямів $\epsilon$ й ейсид-джаз - один з різновидів «легкого» джазу, який сполучає риси джазу та популярної (електронної) музики. В українському соціокультурному просторі ейсид-джаз - нішева музика, яка має невелику, хоча й стабільну аудиторію. У період розквіту цього напряму у світі (1990-ті рр.) представники ейсид-джазу мали неабияку популярність. Одна з ідей ейсид-джазу популяризація джазової музики серед любителів більш популярних музичних напрямів. Однак сьогодні в Україні більш затребуваним $\epsilon$ або «чистий» джаз, або популярна музика, і тому ейсид-джаз, на відміну від західних країн, $€$ андеграундним напрямом.

Розглянемо творчість трьох українських колективів «4.А.Й.К.А», «Jungleman» і «Люk», які позиціонують себе як представники ейсид-джазу з позицій виявлення у них рис андеграунду. Джазовий колектив 3 Дніпра «Jungleman» був створений у 2006 p. і у своій творчості орієнтується на ейсид-джаз, лаунж та етніку. У джазових колах та в рідному Дніпрі колектив доволі відомий, однак широкої популярності не набув, хоча музиканти, що грають у гурті, є виконавцями високого професійного рівня вони працюють і в інших музичних проектах. Також високий рівень музики підтверджує і той факт, що композиції «Tango del Mar» та «Jungleman» посіли відповідно 25 та 34 місце у хіт-параді jazzinua.com, а перша композиція у 2014 р. увійшла у топ-5 європейської музики стилі лаунж. Попри активну концертну діяльність, гурт так і не випустив музичного альбому, він має лише англомовний сайт [8], на якому інформація оновлюється нечасто. Таким чином, гурт «Jungleman» $\epsilon$ колективом, що належить до андеграунду нішевого типу: він відомий і шанований у вузьких колах поціновувачів сучасного джазу - як в Україні, так і у світі. Концертні виступи, зокрема й на місцевому телебаченні, пізніше викладені у YouTube - єдиний спосіб донесення до публіки своєї творчості. Відзначимо й той факт, що музиканти не поспішають спеціально ії популяризувати через випуск диску та кліпів - вже зазначалося, що альбому в гурту «Jungleman» й досі немає, і є лише єдиний кліп, відзнятий на композицію «Wonderlands». Якщо врахувати той факт, що перші композиції гурту мали експериментальний характер, орієнтація тільки на «свого» слухача була закладена на початку існування колективу.

Харківський гурт «4.А.Й.К.А», заснований у 2000 р., у своїй творчості поєднує ейсид-джаз, фанк, даб, лаунж, індастріал, драм-н-бас. Колектив також є популярним у колах любителів джазу та альтернативної музики, однак мало відомий широкому слухачеві. На відміну від гурту «Jungleman», у колективу й досі немає персонального сайту, проте у творчому доробку є цілі три альбоми: «Живой Альбом / Jivoi Albom» 
(2003), «Unknown / Неизвестное» (2006), «Aerodinamika» (2008). Їхні записи також представлені в різних тематичних збірниках. Колектив багато гастролює в Україні та за кордоном, серед досягнень відзначимо присутність у топ-10 альтернативних українських гуртів за версією київського часопису «Афіша».

Отже, гурти «Jungleman» i «4.А.Й.К.А», попри відмінність у стилі та в підходах щодо промоції своєї творчості, є подібними - це високофахові андеграундні колективи нішевого типу. «Нішевість» музики цих гуртів полягає в іiі «неформатності», елітарності, а також відсутності промоції шоу-бізнесового типу, що робить їі практично невідомою широкому загалу.

Ще один харківський гурт «Lюk», створений у 1999 р., своїми стильовими орієнтирами обрав ейсидджаз, фанк, лаундж, easy listening, рок. На відміну від попередніх виконавців, у колективу був свій сайт (російськомовна та англомовна версії), який після розпаду гурту у 2011 р. й досі існує у вигляді веб-архіву [9]. За більш ніж десять років свого існування колектив випустив 3 нестудійні альбоми («Пружина» (1999), «Lюk» (2000), «Lюk + Oйра» (з фолк-тріо «Ойра»), частина музичного матеріалу пізніше увійшла до студійних записів) та 4 студійні («Tourist zone» (2002-2003), «Lemon» (2004), «Sex» (2005), «Мамина Юность» (2009)). Музика гурту «Lюk», на відміну від двох попередніх колективів, більше спрямована на масову аудиторію. Для поширення своєї творчості учасники колективу часто запрошували до співпраці популярних музикантів, наприклад, соліста гурту «5'nizza» Андрія Запорожця. Наявність студійних альбомів та сайту, ротація певних композицій на комерційних радіостанціях частково, але не повністю виводить гурт «Lюk» за межі андеграунду та нішевої музики. Самі музиканти себе вважали андеграундом i в інтерв'ю наголошували на тому, що їхня музика не зрозуміла для широкої аудиторії, що й стало однією 3 причин розпаду гурту.

Наукова новизна роботи полягає в тому, що вперше в українській науці було розглянуто андеграунд в музиці неакадемічної традиції в іiі історичній динаміці, визначено та охарактеризовано два типи андеграундної музики - нонконформістський та нішевий.

Висновки. Андеграунд як підпільне мистецтво в різних типах суспільства має різні соціокультурні функції. У тоталітарних андеграундним $\epsilon$ й елітарне, й масове мистецтво, яке має яскраво виражений нонконформістський характер, а його зміст спрямований на подолання обмеження прав і свобод людини, а також творчого волевиявлення митця. У відкритих суспільствах андеграунд стає своєрідним самовираженням творчої еліти й спрямований на вузьку аудиторію, сьогодні він має яскраво виражений нішевий характер. Творчість українських ейсид-джазових колективів «Jungleman», «4.A.Й.К.A», «Lюk» $\epsilon$ репрезентантом андеграунду пострадянської доби, якому притаманний елітарний характер музики та відсутність промоції шоу-бізнесового типу.

\section{Jimepamypa}

1. Герчанівська П. Е. Культурологія: термінологічний словник. Київ: НАКККіМ, 2015. 439 с.

2. Дружкин Ю. Песня от 70-х до 90-х. Что дальше? Эстрада сегодня и вчера. Москва, 2010. С. 7-53.

3. Євтушенко О. Легенди химерного краю: Українська рок-антологія. Київ: Автограф, 2004. 221 с.

4. Конен В. Рождение джаза. 2-е изд. Москва: Советский композитор, 1990. 320 с.

5. Самая Т. В. Вокальне мистецтво естради як чинник культурного життя України другої половини XX початку XXI століття: дис. ... канд. мистецтвознавства: 26.00.01 «Теорія та історія культури». Київ, 2017. 199 с.

6. Смирна Л. В. Український мистецький нонконформізм як соціокультурний феномен XX століття: дис. ... д-ра мистецтвознавства: спец. 26.00.01. Київ, 2018. 448 с.

7. Январская А. Украинский андеграунд 90-х: опередить время. URL: http://7buttons.kiev.ua/slushaem/ 661-ukrainskij-andegraund-90-kh-operedit-vremya (дата звернення: 22.05.2016).

8. Jungleman (Music is the space jungle). URL: http://www.jungleman.com.ua/ (дата звернення: 3.05.2019).

9. Lюk. Официальный сайт. URL: https://web.archive.org/web/20111224054757/http://www.luk.com.ua/ (дата звернення: 3.05.2019).

\section{References}

1. Herchanivska, P. E. (2015). Cultural Studies: A Terminological Dictionary. Kyiv: NAKKKiM [in Ukrainian].

2. Druzhkin, Yu. (2010). Song from the 70s to the 90s. What's next? Estrada today and yesterday, 7-53 [in Russian].

3. Yevtushenko, O. (2004). Legends of the Chimera Region: Ukrainian Rock Anthology. Kyiv: Autograph [in Ukrainian].

4. Konen, V. (1990). The birth of jazz. 2nd ed. Moscow: Sovetskiy kompositor [in Russian].

5. Samaya, T. V. (2017). The Variety Vocal Art as a Factor in the Cultural Life of Ukraine in the second half of the $20^{\text {th }}-$ beginning of the $21^{\text {t }}$ century. Candidate's thesis. Kyiv: National Academy of Managerial Staff of Culture and Arts [in Ukrainian].

6. Smyrna, L. V. (2017). Ukrainian Artistic Nonconformism as a Socio-Cultural Phenomenon of the XX century. Doctor's thesis. Kyiv: Ukrainian National Tchaikovsky Academy of Music [in Ukrainian].

7. Yanvarskaya, A. (2016). Ukrainskiy andegraund 90-kh: operedit vremia. Retrieved from http://7buttons.kiev.ua/slushaem/661-ukrainskij-andegraund-90-kh-operedit-vremya [in Russian].

8. Jungleman (Music is the space jungle) (2019). Retrieved from http://www.jungleman.com.ua/ [in English]. Russian].

9. Lюk. Official site. (2019). Retrieved from https://web.archive.org/web/20111224054757/http://www.luk.com.ua/ [in 